\title{
Manufacturing technology of AS-SOFC prepared with different commercially available precursors
}

\author{
M. Kawalec ${ }^{1, a}$, R. Kluczowski ${ }^{1}$ and M. Krauz ${ }^{1}$ \\ ${ }^{1}$ Institute of Power Engineering Ceramic Department CEREL
}

\begin{abstract}
Fuel cells are devices converting the chemical energy into the electrical energy and heat as result of the electrochemical reaction between gaseous fuel and a gas oxidant in flameless combustion process. Because of omission of thermo-mechanical steps that are present in any traditional energy conversion technology (e.g. gas turbine) fuel cells show increased efficiency in comparison. Compact sizes and modular scalability predestines this technology for distributed energy generation including but not limited to renewable energy sources (e.g. wind, solar). Fuel cells technology also addresses other very important part of distributed renewable energy generation. Because of the unreliable energy production rates and the usual for renewable energy sources mismatch between energy supply and demand, some sort of energy storage is needed to store surplus of produced energy and release it when needed. Reversible fuel cells, that generate hydrogen from available surplus of energy and then generate energy from that stored fuel when needed are cheaper and more ecologically friendly alternative to usually used batteries. This technology is still under development, including research at IEn OC CEREL. In the early development of reversible fuel cells, new types of nickel oxide and porosity forming carbon was evaluated for this task. This work compares the electrical and mechanical parameters of SOFC manufactured with JT Backer NiO and Carbon Polska carbon with cells made from other commercially available materials. Based on evaluated quality, purity, availability and cost, following materials were selected for comparison: Novamet $\mathrm{NiO}, 99,9 \%$ pure, grain size $1-2 \mu \mathrm{m}$ and Aldrich carbon with parameters similar to graphite used previously. Preliminary tests show clear changes in the microstructural, mechanical and electrical parameters.
\end{abstract}

\section{Introduction}

As part of previous work related to the development of Solid Oxide Fuel Cells [1-9] at IEn OC CEREL, research and development of half-scale manufacturing technology of flat, thin Anode Supported Solid Oxide Fuel Cell (AS-SOFC) with dimensions of $50 \times 50 \mathrm{~mm}$ and $100 \times 100 \mathrm{~mm}$ was conducted. In this technology, anode supports are produced by means of highly reproducible, novel method of high-pressure injection molding and the other functional layers are made by screen printing method [7,9]. Previously, main components of the anode supports were nickel oxide obtained from JT Baker and graphite originating from Carbon Polska, with following parameters supplied by respective manufacturer:

- Nickel Oxide $\mathrm{NiO}$

Manufacturer - J. T. Baker

Average grain size $-2 \mu \mathrm{m}$

Purity - 99,5\%

- Graphite

Manufacturer-Carbon Polska

Average grain size $-1-2 \mu \mathrm{m}$

Purity - min. 99\% mas.
In order to maintain production continuity the need arose for search and usage of new raw materials for anode supports - nickel oxide as well as graphite. Based on our market research, taking into account price, quality and availability, nickel oxide type „F" originating from Novamet and graphite from Aldrich were selected, with following parameters supplied by respective manufacturer:

- Nickel Oxide $\mathrm{NiO}$ - type F

Manufacturer - Novamet

Average grain size $-1-2 \mu \mathrm{m}$

Purity - 99,8\%

- Graphite

Manufacturer- Aldrich

Average grain size $<20 \mu \mathrm{m}$

Purity - min. $99 \%$ mas.

Application of new type of raw materials required trial batch of anode supports and complete fuel cells based on said supports as well as mechanical and electrochemical testing in order to compare the influence of this change on the mechanical and electrochemical parameters and fine tune production process.

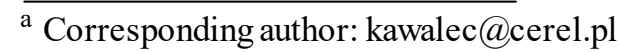




\section{Experimental}

Particle size distributions were determined for both nickel oxide powders using granulometer Mastersizer 2000. Particle size distribution curve and summation particle size curve for both powders are presented in the collective chart (see Figure 1).

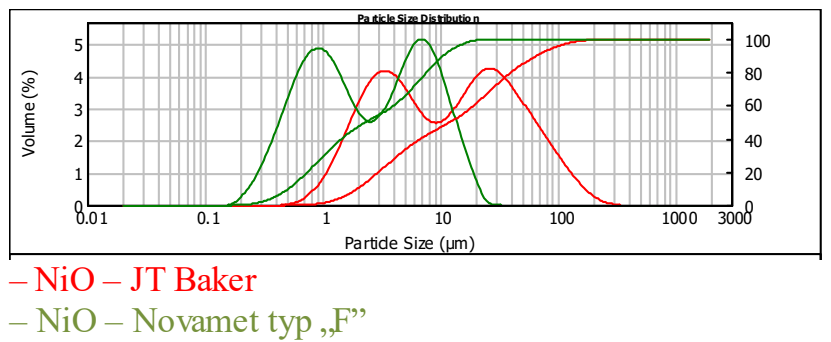

Figure 1. Particle size distribution for different nickel oxide powders.

For both powders $\mathrm{d}_{50}$ had been determined:

- $\mathrm{NiO}$ (JT Baker) - $\mathrm{d}_{50}=12,117 \mu \mathrm{m}$

- $\mathrm{NiO}, \mathrm{F}^{\prime \prime}$ (Novamet) - $\mathrm{d}_{50}=2,340 \mu \mathrm{m}$

In both cases, particle size distribution is bimodal and in the case of nickel oxide from Novamet chart is clearly shifted towards smaller grain size. Average grain size of $\mathrm{NiO}$ powder originating from JT Baker is bigger in comparison to the number provided by the manufacturer. This discrepancy can be explained by differences in measuring methods. $\mathrm{NiO}$ obtained from Novamet corresponded to information from data sheet.

For both types of graphite ignition loss was determined as test of their purity:

SCarbon $=0,85 \%$ mas.

SAldrich $=0,76 \%$ mas

In both cases, remainder of ignition loss does not exceed $1 \%$ mas, which is consistent with provided data. Anode supports dedicated for comparative tests of two types of nickel oxide and two types of graphite were made by high-pressure injection molding. For this task, previously developed raw anode support composition was used, as follows:

Composition 1:

- $\mathrm{NiO}$ (JT Baker) - $66 \%$ mas.

- 8YSZ (TOSOH) - $34 \%$ mas.

- Graphite (Carbon Polska) - 25 \% vol. of powder

- thermoplasticizer

Composition 2:

- $\mathrm{NiO}$ (Novamet) - $66 \%$ mas.

- 8 YSZ (TOSOH) - $34 \%$ mas.

- Grafit (Aldrich) - $25 \%$ vol. of powder

- thermoplasticizer

The prepared mixtures of powders, poreformer and thermoplasticizer were homogenized using an eccentric mixer and a technologic line for pellet production. After homogenization, masses were formed using high-pressure injection molding, obtaining raw anode supports with different kinds of nickel oxide. This process was accomplished by usage of high-pressure injection-molding device BOY XS (Figure 2.) with following base parameters:

- Mold clamping force: $100 \mathrm{kN}$
- Max. injection pressure: 2298 bar

- Max. injection volume: $6,15 \mathrm{~cm} 3$

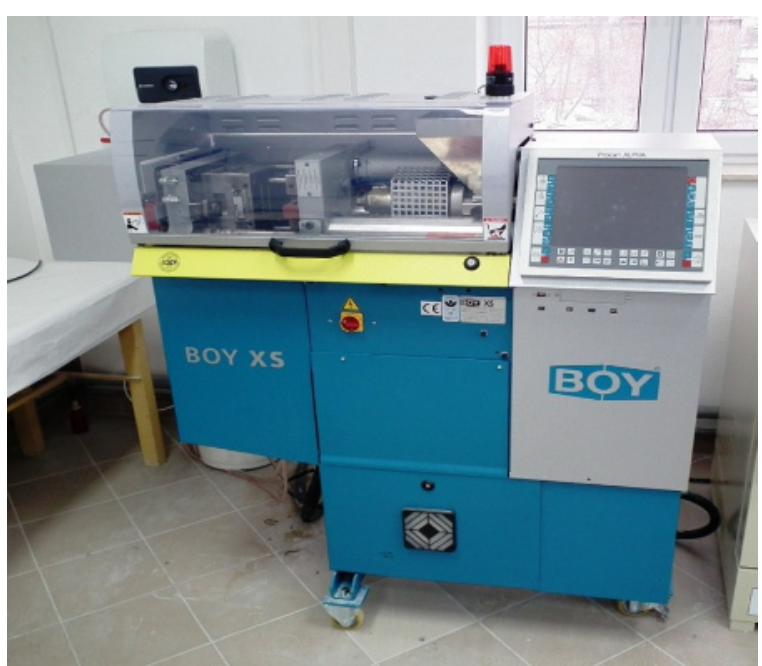

Figure 2. High-pressure injection molding device BOY XS

In order to manufacture anode supports, high-pressure injection mold was used with internal dimensions of $62 \times 62 \times 1.2 \mathrm{~mm}$. Taking sintering shrinkage into account, resulting supports after sintering have dimension of $50 \times 50 \times 1 \mathrm{~mm}$.

There were no significant differences observed at the stage of homogenization or injection molding of prepared anode support in comparison to previously used nickel oxide. Anode supports (Figure 3) were manufactured into full AS-SOFC, using previously developed, optimized composition of individual layers (Figure 4).



Figure 3. Anode support made by injection moulding method



Figure 4. Scheme of solid oxide fuel cell AS-SOFC

- K - Cathode layer - $\mathrm{La}_{0,6} \mathrm{Sr}_{0,4} \mathrm{Fe}_{0,8} \mathrm{Co}_{0,2} \mathrm{O}_{3-\delta}$ (Praxair), thickness $30 \mu \mathrm{m}$, porosity $25 \mathrm{vol} . \%$ 
- BL - barrier layer $\mathrm{Gd}_{0,1} \mathrm{Ce}_{0,9} \mathrm{O}_{2}$ (Praxair), thickness

$2 \mu \mathrm{m}$

- $\mathbf{E}$ - electrolyte 8 YSZ (TOSOH) thickness $4 \mu \mathrm{m}$

- $\mathbf{A F}$ - anode functional layer - NiO/8YSZ(TOSOH)

50/50\% wt., thickness $7 \mu \mathrm{m}$,

- AS - anode support - NiO/8YSZ(TOSOH) 66/34\%

wt., poreformer 25 vol. $\%$, thickness $1,0 \mathrm{~mm}$

- $\mathbf{A K}$ - anode contact layer - NiO, thickness $3 \mu \mathrm{m}$

Manufactured anode supports were debinded and presintered at $1100{ }^{\circ} \mathrm{C}$ for $3 \mathrm{~h}$. All of debinding and presintering processes were conducted in high-temperature electric furnace HT 17/64 HDB (Nabertherm). After this process, anode functional layers $8 \mathrm{YSZ}$ (TOSOH) + $\mathrm{NiO} 1: 1$ and electrolyte layers 8YSZ (TOSOH) were applied using screen printing method on pre-sintered supports. Anode supports based on nickel oxide from Novamet and graphite from Aldrich had significantly lower mechanical strength and cracked during printing process. Anode supports based on previously used nickel oxide (JT Baker) and graphite (Carbon Polska) were not damaged by screen printing process. In order to mitigate this problem, two additional batches of anode supports were sintered, at $1150{ }^{\circ} \mathrm{C}$ and $1180^{\circ} \mathrm{C}$, both with retention time of $3 \mathrm{~h}$. Pre-sintering temperature of $1150{ }^{\circ} \mathrm{C}$ proved to be enough to ensure mechanical strength needed for screen printing process. After deposition of anode functional layer and electrolyte layers, anode supports were air dried at $80{ }^{\circ} \mathrm{C}$ and sintered at $1400{ }^{\circ} \mathrm{C}$ for $3 \mathrm{~h}$. Then, $\mathrm{Gd}_{0,1} \mathrm{Ce}_{0,9} \mathrm{O}_{2}$ (Praxair) layer were deposited using screen printing, dried $\left(75^{\circ} \mathrm{C}\right)$ and sintered at $1350{ }^{\circ} \mathrm{C}$ for $1 \mathrm{~h}$. After sintering, cathode layers of $\mathrm{La}_{0,6} \mathrm{Sr}_{0,4} \mathrm{Fe}_{0,8} \mathrm{Co}_{0,2} \mathrm{O}_{3}-\delta$ (Praxair) were screen printed, dried $\left(75^{\circ} \mathrm{C}\right)$ and sintered at $1100{ }^{\circ} \mathrm{C}$ for $1 \mathrm{~h}$. Completed fuel cells with dimensions of 50x50x1 mm (Figure 5) were tested in order to determinate physical, mechanical and electrochemical properties.

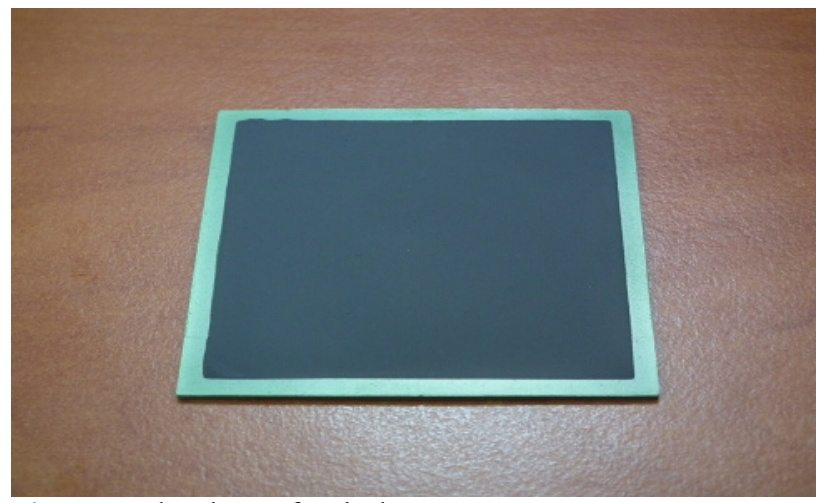

Figure 5. The photo of a single AS-SOFC

\section{Results and discussion}

There were no visual differences observed between different types of manufactured fuel cells. No visible defects, deformation or cracks. Open porosity and apparent density were measured using hydrostatic weighting in water, deflection was measured using Coordinate Measuring Device Crysta-Apexc 7106. Bending tests were conducted using tripoint method on five samples with dimensions $8 \times 10 \times 60 \quad \mathrm{~mm}$ manufactured by means of high-pressure injection molding of corresponding anode mass, debinded and then sintered at $1400{ }^{\circ} \mathrm{C}$ for $3 \mathrm{~h}$. Test results are presented at Table 1.

Table 1. Results of open porosity, apparent density, deflection and bending tests for fuel cells with anode supports based on nickel oxide from JT Backer and Novamet sintered at $1400{ }^{\circ} \mathrm{C}$

\begin{tabular}{|c|c|c|c|c|}
\hline Support & $\begin{array}{c}\text { Open } \\
\text { porosity } \\
{[\%]}\end{array}$ & $\begin{array}{c}\text { Apparent } \\
\text { density } \\
{\left[\mathbf{g} / \mathbf{c m}^{3}\right]}\end{array}$ & $\begin{array}{c}\text { De flec } \\
\text { tion } \\
{[\mathbf{m m}]}\end{array}$ & $\begin{array}{c}\text { Bending } \\
\text { strength } \\
{[\mathbf{M p a}]}\end{array}$ \\
\hline $\begin{array}{c}\text { NiO } \\
\text { (JTBaker) } \\
\text { /8YSZ }\end{array}$ & 26.1 & 4.79 & 0.08 & 131.45 \\
\hline $\begin{array}{c}\text { NiO } \\
\text { (Novamet) } \\
\text { /8YSZ }\end{array}$ & 24.2 & 4.91 & 0.11 & 112.38 \\
\hline
\end{tabular}

Applying new type of $\mathrm{NiO}$ (type F, Novamet) and graphite (Aldrich) resulted in decreased porosity and increased apparent density by about $2 \%$ and decreased bending strength by more than $15 \%$ in comparison to anode supports manufactured with previously used raw materials. Microstructure measurements were conducted on samples using SEM microscope HITACHI S-3400N. Below, microstructure of anode supports before reduction (Figure 6,7) were presented.

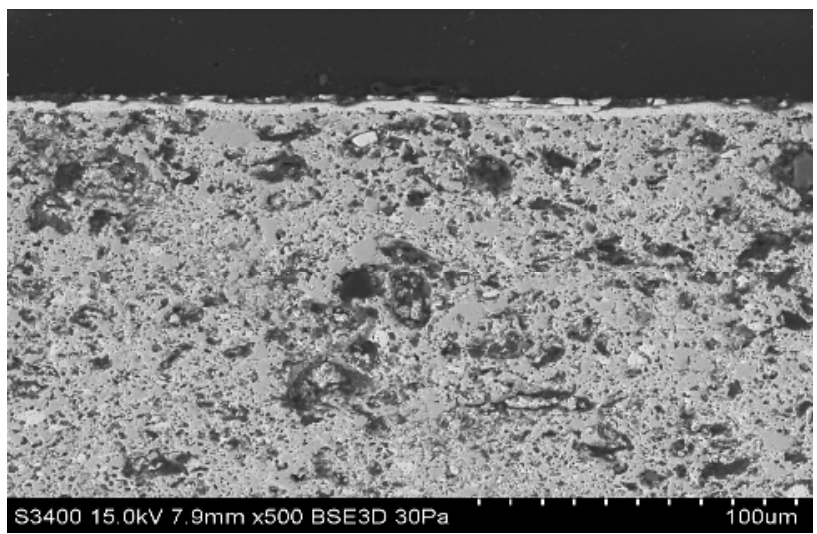

Figure 6. Cross section of microstructure of anode made of composition of $8 \mathrm{YSZ}(\mathrm{TOSOH}) / \mathrm{NiO}$ (JT Baker)

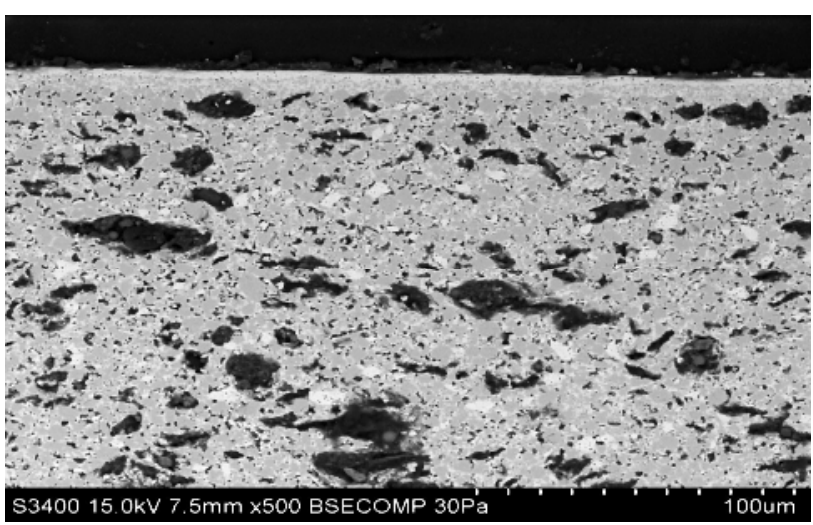

Figure 7. Cross section of microstructure of anode made of composition 8YSZ (TOSOH)/NiO (Novamet) 
In case of anode supports made with nickel oxide from JT Baker and graphite from Carbon Polska (Figure 6) pores have spherical shape. In case of anode supports made with nickel oxide from Novamet and graphite from Aldrich (Figure 7) pores are more elongated with sharp ends in horizontal direction. This can be responsible for lowered mechanical and bending strength as well as lowered electrochemical parameters related to gas fuel transport through the anode. Both types of fuel cells were tested on the specialized single cell test rig. Tests were conducted at temperature of $800 \pm 3{ }^{\circ} \mathrm{C}$, with pure $\mathrm{H}_{2}$ flow of $1.0 \mathrm{Nl} / \mathrm{min}$ acting as fuel and standard air flow of $2.0 \mathrm{Nl} / \mathrm{min}$ as cathode feed. Results of electrical testing were presented below as I-V and I-P curves (Figure 8-9).

Measured open circut voltage (OCV) for both types of fuel cells:

- $\mathrm{OCV}=1,050 \mathrm{~V}-\mathrm{JT}$ Baker

- $\mathrm{OCV}=1,058 \mathrm{~V}$ - Novamet



Figure 8. Polarisation curves U-I recorded for SOFC with anode based on nickel from Novamet and JT Backer

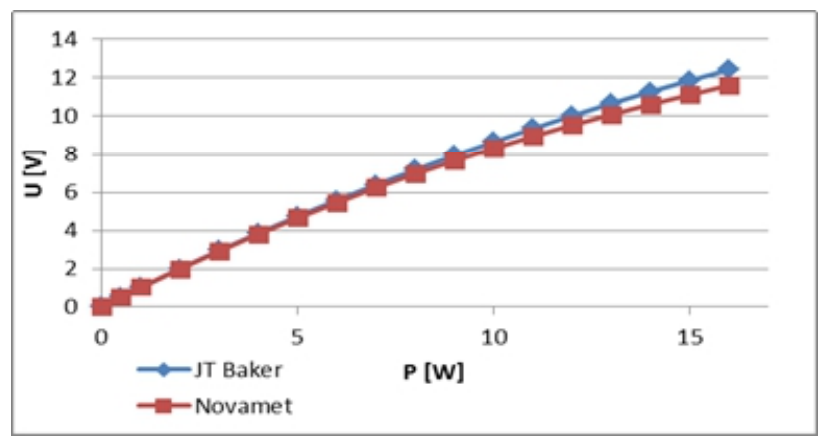

Figure 9. Power-current relation for fuel cells with anode based on nickel from Novamet and JT Backer

As can be gathered from above figures, there are slight differences between the polarization curve of the fuel cell with nickel oxide from Novamet and the one with nickel oxide from JT Backer. Power density with load of $1 \mathrm{~A} / \mathrm{cm}^{2}$ was as follows:

- $0,776 \mathrm{~W} / \mathrm{cm} 2$ - JT Baker

- $0,726 \mathrm{~W} / \mathrm{cm} 2$ - Novamet

In case of fuel cells made with new type of raw material maximum power density decreased by $6 \%$.

\section{Conclusions}

Replacement of base anode support raw materials (NiO-Jt Baker, graphite-Carbon Polska) with ones with similar characteristics (NiO-Novamet, graphite-Carbon Polska) results in changes of mechanical strength, which in turn required significant adjustments to the pre-sintering of anode supports. Additionally, changes were observed in the strength and the electrochemical parameters of fully manufactured cells, which will require additional adjustment to the process parameters in order to maintain established properties of produced SOFC. Research has shown that in case of big, planar fuel cell (above 50x50 $\mathrm{mm}$ in dimension) change in any of base materials, even for one with the same or similar characteristics can lead to significant changes of the production process and the properties of final product.

\section{Acknowledgement}

This work is supported by National Center of Research and Development, as a Sector Program INNOLOT, project EPOCA „Device for power supplying and controlling on-board and ground equipment", um. Nr INNOLOT/I/1/NCBR/2013

\section{References}

1. Z. Rak, R. Kluczowski, M. Krauz, Ceramika 459466, vol. 96 (2006).

2. M. Krauz, K. Krząstek, R. Kluczowski, Conference materials 'XXXI International Conference of IMAPS Poland Chapter" 503-506, Krasiczyn 2326 wrzesień (2007).

3. R. Kluczowski, R. Śliwa, Inżynieria Materiałowa, 925-929, vol. 6 160, (2007).

4. R. Antunes, T. Golec, M. Miller, M. Krauz, R. Kluczowski, K. Krzastek, Journal of Fuel Cell Science and Technology 7 (2010) 011011-1-6.

5. T. Golec, M. Miller, R. Antunes, J. Jewulski, M. Krauz, R. Kluczowski, K. Krzastek, M. Błesznowski,, Journal of Fuel Cell Science and Technology 7 (2010) $011003-1-5$.

6. R. Tomov, M. Krauz, J. Jewulski, S. Hopkins, R. Kluczowski, D. Głowacka, B. Głowacki, Journal of Power Sources, 195 (2010) 7160-7167

7. R. Kluczowski, M. Krauz, M. Kawalec, J.P. Ouweltjes, Journal of Power Sources 268 (2014) $752-757$

8. R. I. Tomov, M. Krauz, A. Tluczek, R. Kluczowski, Venkatesan V. Krishnan, K. Balasubramanian, R.V.Kumar, B. A. Glowacki, Mater Renew Sustain Energy (2015) 4:14

9. Praca zbiorowa pod redakcją naukową T. Golca, R. Kluczowski, M . Krauz, M. Kawalec, rozdz. "Wytwarzanie $i$ charakterystyka ogniw SOFC", Wydawnictwo Naukowe Instytutu Technologii Eksploatacji - PIB, Warszawa (2015) 